\title{
NEWMAN ERROR ANALYSIS SISWA MADRASAH DALAM MENYELESAIKAN SOAL CERITA MATEMATIKA
}

\author{
Marni Zulyanty \\ Universitas Islam Negeri Sulthan Thaha Saifuddin Jambi, Jln. Jambi Ma. Bulian KM 16 Sei. Duren Jambi \\ marnizulyanty@uinjambi.ac.id
}

\begin{abstract}
Students' mistakes in solving the mathematical word problem is still a problem so it must be identified for each stage of solving. It is done so that the solutions offered are more effective. One way to identify the stage of solving of mathematical problem is the Newman Error Analysis stage. So the purpose of this research is to describe the ability of students of Islamic Junior High School to solve mathematical problems in the form of word problem and to describe the mistakes of high-ability Islamic High School students in mathematical word problem based on Newman Error Analysis. The approach used is qualitative descriptive. The research subject is the high-ability in Islamic Junior High School of Jambi City. Students are asked to work on solving questions in the form of word problems. Then the student interviewed about the mistakes that were made when solving the word problems given for each of the stages. The results showed $56 \%$ of high-ability students encountered an error while solving the algebra operation and $44 \%$ of high-ability students encountered an error while solving Pythagoras theorem. As for the errors that occur in high-ability students if in the analysis based on the stage of Newman Error Analysis occurs at the stage of understanding the problem (comprehension) and the problem transformation (transformation). Of course, errors in the comprehension and transformation cause errors at a later stage so that the solution or answer found is worth wrong.
\end{abstract}

Keywords: Error, Newman Error Analysis, Mathematical Word Problem.

\begin{abstract}
Abstrak
Kesalahan siswa dalam menyelesaikan soal cerita matematika masih menjadi masalah sehingga harus di identifikasi untuk setiap tahapan penyelesaiannya. Hal ini dilakukan agar solusi yang ditawarkan menjadi lebih efektif. Salah satu cara mengidentifikasi tahapan penyelesaian soal cerita matematika adalah tahapan Newman Error Analysis. Sehingga tujuan dari penelitian ini adalah mendeskripsikan kemampuan siswa madrasah dalam memecahkan masalah matematika dalam bentuk soal cerita dan mendeskripsikan kesalahan siswa madrasah berkemampuan tinggi dalam menyelesaikan soal cerita matematika berdasarkan Newman Error Analysis. Pendekatan yang digunakan adalah kualitatif deskriptif. Adapun subjek penelitian adalah siswa Madrasah Tsanawiyah Negeri Kota Jambi yang berkemampuan tinggi. Siswa diminta mengerjakan lembar soal pemecahan masalah dalam bentuk soal cerita. Kemudian siswa diwawancara seputar kesalahan yang dilakukan saat menyelesaikan soal cerita yang diberikan untuk setiap tahapannya. Hasil penelitian menunjukkan 56\% siswa kemampuan tinggi mengalami kesalahan saat menyelesaikan soal materi operasi aljabar dan $44 \%$ siswa kemampuan tinggi mengalami kesalahan saat menyelesaikan soal materi teorema Pythagoras. Adapun kesalahan yang terjadi pada siswa kemampuan tinggi jika di analisis berdasarkan tahapan Newman Error Analysis terjadi pada tahap memahami masalah (comprehension) dan tahap transformasi masalah (transformation). Tentunya kesalahan pada tahap comprehension dan transformation ini menyebabkan kesalahan pada tahap selanjutnya sehingga solusi atau jawaban yang ditemukan bernilai salah.
\end{abstract}

Kata kunci: Kesalahan, Analisis Kesalahan Newman, Soal Cerita Matematika.

Matematika sangat erat dengan kehidupan sehari-hari. Bahkan matematika diajarkan kepada manusia baik secara formal melalui sekolah dan secara tidak formal melalui kehidupan. Di jenjang sekolah, matematika adalah salah satu mata pelajaran yang dipelajari siswa mulai dari jenjang terendah sampai tertinggi. Namun faktanya banyak kesulitan yang dialami siswa dalam belajar matematika. Salah satu aspek kesulitan yang dialami siswa dalam belajar matematika adalah dalam memecahkan masalah matematika. Faktanya memecahkan masalah adalah tujuan yang paling penting dalam pembelajaran matematika (B, Sahar \& AT, Rohani, 2010), dan untuk meningkatkan kemampuan memecahkan masalah digunakan masalah matematika (Adebola \& Sakiru, 2012).

Selain itu, menurut NCTM (2000) terdapat lima standar proses dalam pembelajaran 
matematika, dan salah satunya adalah memecahkan masalah matematika (mathematical problem solving). Namun faktanya kemampuan siswa Indonesia dalam memecahkan masalah masih rendah jika dibandingkan dengan negara lain. Oleh karenanya perlu adanya peningkatan kemampuan pemecahan masalah siswa di Indonesia. Bentuk dari soal pemecahan masalah matematika adalah soal cerita matematika (D, Setyono \& S, Sutarni, 2013). Masalah matematika dapat berupa soal non rutin yaitu soal cerita yang membutuhkan penyelesaian yang melibatkan tingkat penalaran lebih lanjut.

Mengetahui letak dan bentuk kesalahan siswa dalam menyelesaikan soal cerita akan dapat membantu guru dalam meningkatkan kemampuan pemecahan masalah siswa. Untuk mengetahui letak dan bentuk kesalahan tersebut, dapat dilakukan dengan menganalisis kesalahan siswa dengan menggunakan Newman Error Analysis. Newman Error Analysis dipilih karena memiliki kredibilitas yang tinggi (A.L. White, 2005). Menurut A.L. White (2010) terdapat 5 tahap dalam Newman Error Analysis, yaitu membaca masalah (reading), memahami masalah (comprehension), transformasi masalah (transformation), keterampilan proses (process skill), dan penulisan jawaban akhir (encoding). Diharapkan dengan menggunakan Newman Error Analysis letak dan bentuk kesalahan siswa dalam menyelesaikan soal cerita tergambar jelas dan detail.

Penelitian sebelumnya yang relevan dilakukan oleh Tello, E.A (2010) menunjukkan bahwa siswa dapat sukses dalam problem solving dengan membuat keputusan yang berhubungan dengan informasi dari masalah yang diberikan, memilih pendekatan yang dibutuhkan untuk membantu memecahkan masalah dan akhirnya menemukan solusi dari masalah. Sehingga proses yang dilakukan untuk memecahkan masalah tidak hanya membuat model matematika dari masalah yang diberikan melainkan menemukan solusi dari masalah.

Selain itu hasil penelitian Sajadi M, Amiripour P, \& Malkhalifeh M.R (2013) menunjukkan bahwa Problem solving adalah suatu proses yang lebih daripada sekedar membuat model matematika dari suatu situasi. Situasi yang dimaksud adalah masalah atau persoalan yang penyelesaianya berhubungan dengan matematika. Dan oleh karenanya dalam pembelajaran matematika Problem solving ini perlu diajarkan dan dilatih kepada siswa.

Berdasarkan uraian di atas, maka tujuan penelitian ini adalah mendeskripsikan kemampuan siswa madrasah dalam memecahkan masalah matematika dalam bentuk soal cerita dan mendeskripsikan kesalahan siswa madrasah berkemampuan tinggi dalam menyelesaikan soal cerita matematika berdasarkan Newman Error Analysis.

\section{METODE}

Penelitian ini menggunakan pendekatan kualitatif dengan jenis penelitian deskriptif. Pendekatan kualitatif ditujukan untuk mengungkapkan suatu masalah dan mengembangkannya secara detail untuk memahami pusat fenomena dari suatu masalah (Creswell, 2012). Adapun subjek penelitian adalah siswa Madrasah Tsanawiyah Negeri yang ada di Kota Jambi yang berkemampuan tinggi. Karena penelitian ini menggunakan pendekatan penelitian kualitatif maka instrumen pengumpulan data terbagi 
dua yaitu instrumen utama yakni peneliti sendiri dan instrumen pendukung yakni lembar soal pemecahan masalah matematika dan pedoman wawancara. Sementara analisis data dalam penelitian ini menggunakan analisis data Creswell yang terdiri atas enam tahap yakni (1) menyiapkan dan mengumpulkan data untuk dianalisis, (2) mengembangkan dan mengkode data, (3) membuat kode berdasarkan deskripsi-deskripsi, (4) menyajikan dan melaporkan hasil yang ditemukan, (5) menginterpretasikan hasil yang ditemukan, (6) memvalidasi keakuratan dari hasil yang ditemukan.

\section{HASIL}

Instumen lembar soal pemecahan masalah matematika digunakan untuk melihat kemampuan siswa dalam memecahkan masalah matematika. Selain itu lembar soal juga dapat memberikan data kesalahan yang dilakukan siswa dalam memecahkan masalah matematika. Lembar soal pemecahan masalah matematika ini disajikan dalam bentuk soal cerita dan disusun pada materi operasi aljabar dan aplikasi Pythagoras. Masalah operasi aljabar dan masalah aplikasi Pythagoras yang diberikan ini merupakan soal yang sesuai dengan Kompetensi Inti ranah keterampilan (KI-4) karena sudah memerlukan strategi dan pola pikir panjang dalam menyelesaikan masalah tersebut. Selanjutnya instrumen pedoman wawancara berguna untuk membimbing peneliti dalam memastikan terjadinya tahapan Newman Error Analysis saat siswa memecahkan masalah matematika yang diberikan. Instumen pedoman wawancara ini disusun berdasarkan tahapan Newman Error Analysis dalam memecahkan masalah matematika.

Penelitian ini dilakukan di Madrasah Tsanawiyah Negeri Kota Jambi. Terdapat 6 sekolah Madrasah Tsanawiyah Negeri Kota Jambi yaitu MTs Negeri 1 Kota Jambi, MTs Negeri 2 Kota Jambi, MTs Negeri 3 Kota Jambi, MTs Negeri 4 Kota Jambi, MTs Negeri 5 Kota Jambi, dan MTs Negeri 6 Kota Jambi. Setiap sekolah diambil 3 siswa dengan kriteria siswa berkemampuan tinggi. Jadi total subjek penelitian 18 siswa berkemampuan tinggi.

\section{Hasil Pengerjaan Lembar Soal Pemecahan Masalah Matematika}

Hasil pengerjaan lembar soal pemecahan masalah ini terdiri dari lima kriteria penilaian, yaitu benar secara utuh (B), benar tapi tidak menemukan solusi (BTS), salah secara utuh (S), salah langkah pengerjaan (SL), dan tidak jawab (TJ). Adapun hasil pengerjaan lembar soal pemecahan masalah matematika siswa seperti pada tabel 1 berikut.

\section{Tabel 1}

Hasil Pengerjaan Lembar Soal Pemecahan Masalah Matematika Subjek

\begin{tabular}{|l|c|c|c|c|c|c|c|c|c|c|}
\hline \multicolumn{1}{|c|}{ Soal } & $\boldsymbol{B}$ & $\boldsymbol{\%}$ & $\boldsymbol{B T S}$ & $\boldsymbol{\%}$ & $\boldsymbol{S}$ & $\boldsymbol{\%}$ & $\boldsymbol{S L}$ & $\boldsymbol{\%}$ & $\boldsymbol{T J}$ & $\boldsymbol{\%}$ \\
\hline Operasi Aljabar & 7 & 39 & 0 & 0 & 10 & 56 & 0 & 0 & 1 & 6 \\
\hline Teorema Pythagoras & 7 & 39 & 3 & 17 & 8 & 44 & 0 & 0 & 0 & 0 \\
\hline
\end{tabular}


Dari Tabel 1 terlihat bahwa persentase kesalahan yang dialami siswa saat menyelesaikan lembar soal matematika masih tinggi. Dalam penelitian ini kategori siswa dikatakan mengalami kesalahan jika penilaian terhadap lembar jawaban adalah kriteria salah secara utuh (S) dan salah langkah pengerjaan (SL). Tabel 2 berikut menyajikan persentase kesalahan subjek saat menyelesaikan lembar soal pemecahan masalah matematika.

Tabel 2

Persentase Kesalahan Subjek

\begin{tabular}{|l|c|c|}
\hline \multicolumn{1}{|c|}{ Soal } & Frekuensi & \% \\
\hline Operasi Aljabar & 10 & 56 \\
\hline Teorema Pythagoras & 8 & 44 \\
\hline
\end{tabular}

\section{Hasil Penelitian Subjek Kemampuan Tinggi}

Subjek kemampuan tinggi dalam penelitian ini terdiri dari 18 siswa. Dari persentase kesalahan seperti pada Tabel 2 ada 56\% siswa kemampuan tinggi yang mengalami kesalahan saat menyelesaikan soal materi operasi aljabar. Selain itu ada $44 \%$ siswa kemampuan tinggi yang mengalami kesalahan saat menyelesaikan soal materi teorema Pythagoras. Kesalahan siswa kemampuan tinggi dalam menyelesaikan soal operasi aljabar dan teorema Pythagoras berdasarkan tahapan Newman Error Analysis tergambar seperti pada Tabel 3 beikut.

\section{Tabel 3}

Kesalahan Siswa Kemampuan Tinggi

\begin{tabular}{|l|c|l|c|l|}
\hline \multirow{2}{*}{ Tahapan } & \multicolumn{2}{|c|}{ Operasi Aljabar } & \multicolumn{2}{c|}{ Teorema Pythagoras } \\
\cline { 2 - 4 } & $\%$ & Jenis Kesalahan & \% & Jenis Kesalahan \\
\hline Reading & - & & - & \\
\hline Comprehension & 50 & Memaknai & - & \\
\hline Transformation & 100 & Penjumlahan & 100 & Rumus L $\Delta$ \\
\cline { 2 - 3 } & & Bilangan kelipatan 8 & & $\begin{array}{l}\text { Penjumlahan } \\
\text { pengurangan }\end{array}$ \\
\cline { 5 - 6 } & & & & Pembagian perkalian \\
\hline Process skill & - & & - & \\
\hline Encoding & 30 & Memaknai & 87.5 & Memaknai \\
\hline
\end{tabular}

\section{Kesalahan Penyelesaian Soal Materi Operasi Aljabar}

Terdapat 10 subjek siswa kemampuan tinggi yang mengalami kesalahan saat menyelesaikan soal operasi aljabar. Selanjutnya kesepuluh subjek ini disebut KTA1, KTA2, .., KTA10. Kesalahan ini terlihat jelas pada lembar jawaban subjek dan saat wawancara subjek. Secara umum kesalahan ini dialami oleh siswa kemampuan tinggi di tiga MTs Negeri Kota Jambi dari enam MTs Negeri Kota Jambi. Berdasarkan lembar jawaban subjek, kesalahan yang dialami ini bersumber pada satu hal yaitu pemahaman soal dan kegagalan dalam memilih rumus yang tepat untuk menyelesaikan soal. 
Terkait tahapan Newman Error Analysis subjek saat menyelesaikan lembar soal pemecahan masalah matematika dapat dilihat pada lembar jawaban. Indikator pertama tahapan Newman Error Analysis yaitu membaca soal dengan baik telah dipenuhi dan dilalui oleh semua subjek siswa kemampuan tinggi (KTA1, KTA2, ..., KTA10). Hal ini dapat dibuktikan dengan adanya usaha yang ditulis subjek di lembar jawaban sesuai dengan semesta soal yang diberikan. Hal ini seperti pada Gambar 1 berikut. Selain itu dalam wawancara subjek juga menjelaskan bahwa tidak mengalami kesulitan saat membaca soal. Sehingga subjek siswa kemampuan tinggi telah memenuhi indikator membaca soal dengan baik saat menyelesaikan soal materi operasi aljabar.

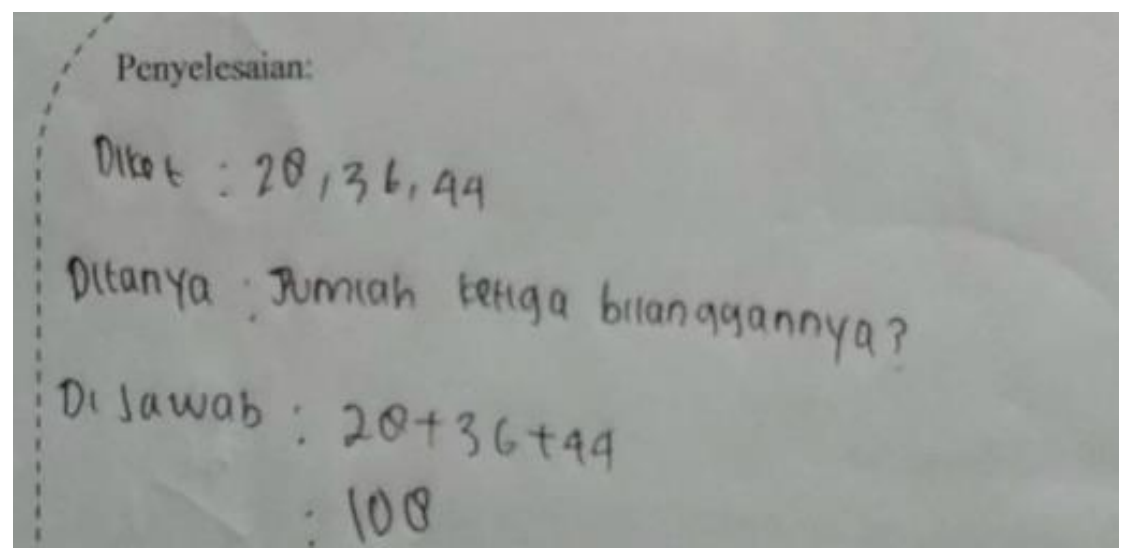

Gambar 1. Jawaban Subjek KTA1 untuk Soal No. 1

Selanjutnya untuk indikator kedua adalah identifikasi ciri masalah juga telah dilalui dan dipenuhi oleh subjek KTA1, KTA2, ..., KTA10 dengan baik. Namun kebenaran dari identifikasi ciri masalah yang dilalui subjek tidak sepenuhnya benar, ada 50\% dari subjek yang mengalami kesalahan melakukan identifikasi ciri masalah dengan benar yaitu KTA6, KTA7, KTA8, KTA9, dan KTA10, sedangkan 50\% lagi masih mengalami kegagalan dalam mengidentifikasi masalah yaitu KTA1, KTA2, KTA3, KTA4, dan KTA5. Hal ini terlihat dari lembar jawaban soal dan wawancara. Subjek dalam melakukan identifikasi ciri masalah dapat menentukan informasi atau yang diketahui pada soal dan apa yang ditanyakan pada soal. Subjek yang mengalami kegagalan dalam mengidentifikasi masalah ini disebabkan karena subjek menganggap keterangan pada soal yang mengatakan bahwa “... jumlah dari masing dua bilangan tersebut secara berturut-turut adalah 28, 36, 44" memberikan informasi bahwa nilai 28,36 , dan 44 adalah nilai dari masing-masing bilangan yang ditanyakan. Hal ini dapat dilihat pada Gambar 2.1 di atas. Dengan demikian subjek siswa kemampuan tinggi telah memenuhi indikator identifikasi ciri masalah dalam menyelesaikan soal materi operasi aljabar.

Indikator ketiga tahapan Newman Error Analysis yaitu merencanakan aktivitas pemecahan masalah telah dilalui dan dipenuhi oleh subjek KTA1, KTA2, ..., KTA10 dengan baik. Hal ini dapat dilihat dari lembar jawaban subjek dan dari wawancara. Subjek dalam merencanakan aktivitas pemecahan masalah ini telah dapat menemukan model matematika dari masalah operasi aljabar yang diberikan dan menemukan rumus yang sesuai dengan model matematika yang dibuat. Kesalahan dalam menentukan 
model dan rumus untuk menyelesaikan soal ini di alami subjek karena berdasarkan identifikasi ciri masalah yang telah dilewati sebelumnya memang ada kesalahan sehingga untuk tahap berikutnya juga mengalami kesalahan. Sehingga subjek siswa kemampuan tinggi telah memenuhi indikator merencanakan aktivitas pemecahan masalah dalam menyelesaikan soal materi operasi aljabar.

Berikutnya indikator memecahkan masalah juga telah dipenuhi dan dilalui subjek KTA1, KTA2, ..., KTA10 dengan baik. Hal ini terlihat pada lembar jawaban dan dalam wawancara. Dari lembar jawaban terlihat bahwa subjek telah memecahkan masalah operasi aljabar yang diberikan sesuai dengan model dan rumus yang didapat pada tahap sebelumnya. Saat memecahkan masalah ini subjek tidak mengalami kesulitan dan langkah pengerjaan yang telah dilakukan juga sudah sesuai dengan model dan rumus yang ditentukan sebelumnya walaupun rumus dan model yang digunakan bernilai salah. Berdasarkan uraian diatas maka subjek siswa kemampuan tinggi telah memenuhi indikator memecahkan masalah dalam menyelesaikan soal materi operasi aljabar.

Indikator selanjutnya adalah kesimpulan proses pemecahan masalah, pada indikator ini terdapat $30 \%$ subjek gagal dalam menuliskan kesimpulan yaitu KTA1, KTA7, dan KTA10. Sedangkan 70\% subjek telah melalui dan memenuhi indikator kesimpulan proses pemecahan masalah ini. Kesimpulan yang dituliskan oleh $70 \%$ subjek ini sesuai dengan semesta masalah soal yang diberikan, walaupun kesimpulan yang dituliskan bernilai salah. Sementara untuk $30 \%$ subjek yang gagal menuliskan kesimpulan ini mengatakan bahwa subjek lupa untuk menuliskan kesimpulan karena subjek terbiasa menyelesaikan soal cerita hanya sebatas penemuan nilai jawaban. Hal ini dapat dilihat dari lembar jawaban subjek dan wawancara. Karena persentase subjek yang memenuhi tahap kesimpulan proses pemecahan masalah lebih besar daripada yang tidak memenuhi maka subjek siswa kemampuan tinggi telah memenuhi indikator kesimpulan proses pemecahan masalah dalam menyelesaikan soal materi operasi aljabar.

\section{Kesalahan Penyelesaian Soal Materi Teorema Pythagoras}

Terdapat 8 subjek siswa kemampuan tinggi yang mengalami kesalahan saat menyelesaikan soal teorema Pythagoras. Selanjutnya kedelapan subjek ini disebut KTP1, KTP2, .., KTP8. Kesalahan ini terlihat jelas pada lembar jawaban subjek dan saat wawancara subjek. Secara umum kesalahan ini dialami oleh siswa kemampuan tinggi di tiga MTs Negeri Kota Jambi dari enam MTs Negeri Kota Jambi. Berdasarkan lembar jawaban subjek, kesalahan yang dialami ini bersumber pada satu hal yaitu pemahaman soal dan kegagalan dalam memilih rumus yang tepat untuk menyelesaikan soal.

Terkait tahapan Newman Error Analysis subjek saat menyelesaikan lembar soal pemecahan masalah matematika dapat dilihat pada lembar jawaban. Indikator pertama tahapan Newman Error Analysis yaitu membaca soal dengan baik telah dipenuhi dan dilalui oleh semua subjek siswa kemampuan tinggi (KTP1, KTP2, .., KTP8). Hal ini dapat dibuktikan dengan adanya usaha yang ditulis subjek di lembar jawaban sesuai dengan semesta soal yang diberikan seperti pada Gambar 2 Selain itu dalam wawancara subjek juga menjelaskan bahwa tidak mengalami kesulitan saat membaca 
soal. Sehingga subjek siswa kemampuan tinggi telah memenuhi indikator membaca soal dengan baik saat menyelesaikan soal materi teorema Pythagoras.

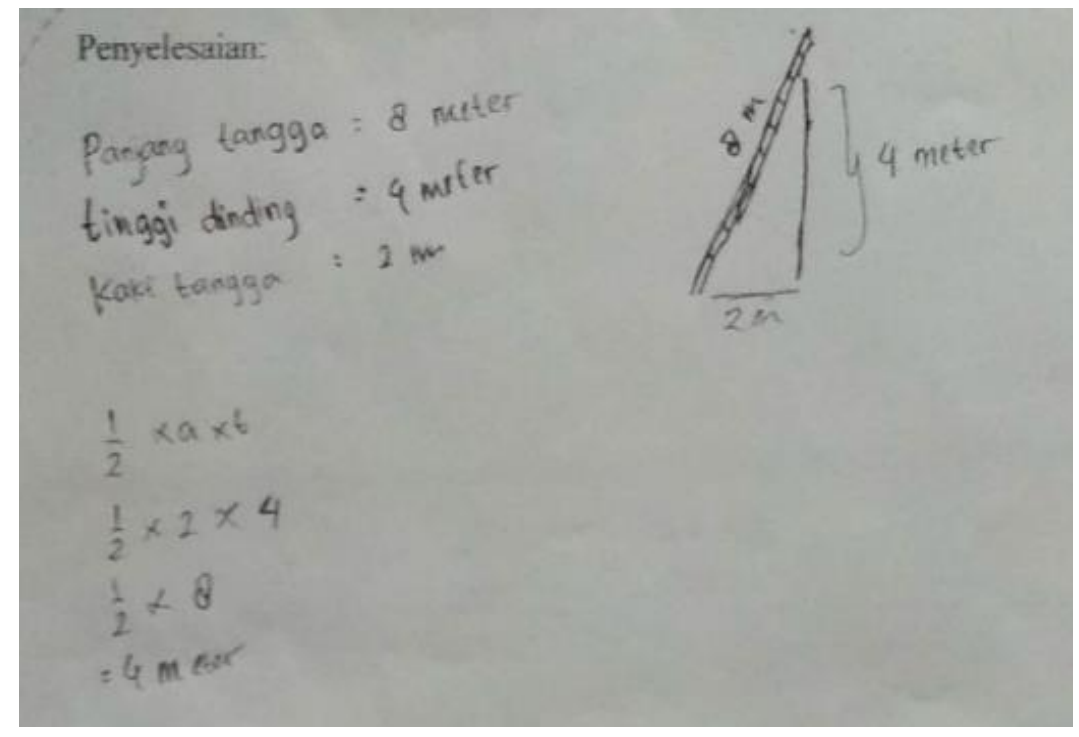

Gambar 2. Jawaban Subjek KTP1 untuk Soal No. 2

Selanjutnya untuk indikator kedua adalah identifikasi ciri masalah juga telah dilalui dan dipenuhi oleh subjek KTP1, KTP2, .., KTP8 dengan baik. Nilai kebenaran dari identifikasi ciri masalah yang dilalui subjek juga sudah benar. Hal ini terlihat dari lembar jawaban soal dan wawancara. Subjek dalam melakukan identifikasi ciri masalah dapat menentukan informasi atau yang diketahui pada soal dan apa yang ditanyakan pada soal. Dengan demikian subjek siswa kemampuan tinggi telah memenuhi indikator identifikasi ciri masalah dalam menyelesaikan soal materi teorema Pythagoras.

Indikator ketiga tahapan Newman Error Analysis yaitu merencanakan aktivitas pemecahan masalah telah dilalui dan dipenuhi oleh subjek KTP1, KTP2, .., KTP8 dengan baik. Hal ini dapat dilihat dari lembar jawaban subjek dan dari wawancara. Subjek dalam merencanakan aktivitas pemecahan masalah ini telah dapat menemukan model matematika dari masalah teorema Pythagoras yang diberikan dan menemukan rumus yang sesuai dengan model matematika yang dibuat walaupun model dan rumus yang digunakan tersebut salah. Kesalahan dalam menentukan model dan rumus untuk menyelesaikan soal ini di alami subjek karena subjek gagal dalam mentransformasikan masalah ke dalam kajian matematika sehingga terjadi kesalahan dalam memilih rumus untuk menyelesaikan soal.

Subjek KTP1 salah karena dalam menyelesaikan soal menggunakan rumus luas segitiga. Subjek KTP2, KTP4, KTP5, KTP6, KTP7, dan KTP8 salah karena menggunakan operasi penjumlahan dan operasi pengurangan. KTP3 salah karena menggunakan operasi perkalian dan operasi pembagian. Dari paparan diatas maka subjek siswa kemampuan tinggi telah memenuhi indikator merencanakan aktivitas pemecahan masalah dalam menyelesaikan soal materi teorema Pythagoras.

Berikutnya indikator memecahkan masalah juga telah dipenuhi dan dilalui subjek KTP1, KTP2, ..., KTP8 dengan baik. Hal ini terlihat pada lembar jawaban dan wawancara. Dari lembar jawaban terlihat bahwa subjek telah memecahkan masalah teorema Pythagoras yang diberikan sesuai dengan model dan 
rumus yang didapat pada tahap sebelumnya. Saat memecahkan masalah ini subjek tidak mengalami kesulitan dan langkah pengerjaan yang telah dilakukan juga sudah sesuai dengan model dan rumus yang ditentukan sebelumnya walaupun rumus dan model yang digunakan bernilai salah. Berdasarkan uraian diatas maka subjek siswa kemampuan tinggi telah memenuhi indikator memecahkan masalah dalam menyelesaikan soal materi teorema Pythagoras.

Indikator selanjutnya adalah kesimpulan proses pemecahan masalah, pada indikator ini terdapat $87,5 \%$ subjek gagal dalam menuliskan kesimpulan. Hanya 12,5\% subjek telah melalui dan memenuhi indikator kesimpulan proses pemecahan masalah ini yaitu KTP4. Kesimpulan yang dituliskan oleh $12,5 \%$ subjek ini sesuai dengan semesta masalah soal yang diberikan, walaupun kesimpulan yang dituliskan bernilai salah. Sementara untuk $87,5 \%$ subjek yang gagal menuliskan kesimpulan ini mengatakan bahwa subjek lupa untuk menuliskan kesimpulan karena subjek terbiasa menyelesaikan soal cerita hanya sebatas penemuan nilai jawaban. Selain itu pada wawancara subjek mengatakan bahwa tidak menuliskan kesimpulan karena belum yakin dengan jawaban yang ditemukan. Karena persentase subjek yang tidak memenuhi tahap kesimpulan proses pemecahan masalah lebih besar daripada yang memenuhi maka subjek siswa kemampuan tinggi belum memenuhi indikator kesimpulan proses pemecahan masalah dalam menyelesaikan soal materi teorema Pythagoras.

Berdasarkan uraian di atas, maka secara umum siswa kemampuan tinggi dalam menyelesaikan soal cerita matematika masih mengalami kesalahan. Kesalahan ini terjadi terutama saat menyelesaikan soal cerita terkait materi aljabar dan teorema Pythagoras. Ada beberapa bentuk kesalahan yang dialami siswa kemampuan tinggi.

Adapun kesalahan yang terjadi pada siswa kemampuan tinggi jika di analisis berdasarkan tahapan Newman Error Analysis dikarenakan adanya kesalahan pada tahap memahami masalah (comprehension). Berdasarkan hasil pengerjaan siswa melalui lembar jawaban dan hasil wawancara, pada tahap ini kesalahan ditandai dengan tidak mampunya siswa mengidentifikasi informasi yang diketahui dan yang ditanyakan pada soal dengan benar. Hal ini yang menyebabkan siswa salah dalam menyelesaikan soal atau tidak dapat menemukan solusi yang tepat. Hal ini sesuai dengan hasil observasi Piaget (L.S. Shulman, 1970) yang menunjukkan bahwa kesalahan siswa menyebabkan tidak ditemukannya solusi yang tepat.

Selain kesalahan pada tahap memahami masalah (comprehension), kesalahan siswa kemampuan tinggi dalam menyelesaikan soal cerita yang diberikan adalah kesalahan pada tahap transformasi masalah (transformation). Pada tahap ini siswa mengalami kesalahan dalam menemukan hubungan antar informasi pada soal dan gagal dalam menemukan rumus atau strategi yang tepat untuk menyelesaikan soal. Hal ini sejalan dengan hasil penelitian Radatz, H (2013) yang menunjukkan bahwa kebanyakan siswa salah dalam mengartikan bahasa matematika. Selain itu solusi dari masalah cerita matematika lebih khusus adalah bagaimana mentranslasikan bahasa atau bentuk masalah ke dalam bahasa matematika yang sesuai ( Aiken, 1972; Kane, Byme \& Hater, 1974; Pippig, 1977). Hal ini juga menyebabkan siswa salah dalam menyelesaikan soal atau tidak dapat menemukan solusi yang tepat. 


\section{KESIMPULAN}

Siswa madrasah dalam memecahkan masalah matematika dalam bentuk soal cerita masih mengalami kesalahan terutama saat memecahkan masalah operasi aljabar dan teorema Pythagoras. Kesalahan ini dapat berupa kesalahan dalam hal memahami masalah, kesalahan dalam proses penggunaan rumus, dan kesalahan pada solusi yang ditemukan. Sementara kesalahan siswa madrasah berkemampuan tinggi dalam menyelesaikan soal cerita matematika materi operasi aljabar berdasarkan Newman Error Analysis terjadi pada tahap comprehension. Kesalahan ini terjadi berupa kesalahan dalam hal memaknai atau mengartikan soal cerita yang diberikan. Sementara kesalahan siswa madrasah berkemampuan tinggi dalam menyelesaikan soal cerita matematika materi teorema Pythagoras berdasarkan Newman Error Analysis terjadi pada tahap transformation. Kesalahan ini terjadi berupa kesalahan dalam hal mentransformasikan soal cerita yang diberikan yang berujung pada kesalahan penentuan rumus atau konsep dalam menyelesaikan soal. Tentunya kesalahan pada tahap comprehension dan transformation ini menyebabkan kesalahan pada tahap selanjutnya sehingga menyebabkan solusi atau jawaban dari soal cerita yang ditemukan bernilai salah.

\section{DAFTAR PUSTAKA}

Adebola \& Sakiru. (2012). A Problem Solving Model as a Strategy for Improving Secondary School Students' Achievement and Retention in Further Mathematics. ARPN Journal of Science and Technology, 2 (2), 122-130.

Aiken, L. R. (1972). Language factors in learning mathematics. Review of Educational Research, 42, 359-385.

A.L. White. (2005). Learning Mathematics in Classroom: Finding Out Why Children Make Mistakesand then Doing Something to Help Them. Sydney: Universitty of Western Sydney.

A.L. White. (2010). Numeracy, Literacy, and Newman's Error Analysis. Journal of Sciences and Mathematics Education in Southeast Asia, 33 (2), 129-148.

B, Sahar \& AT, Rohani. (2010). Assessing Cognitive and Metacognitive Strategies during Algebra Problem Solving Among University Students. Procedia Social and Behavioral Sciences, 8, 403410 .

Creswell. (2012). Educational Research “Planning, Conducting, and Evaluating Quantitative and Qualitative Research. Amerika: Pearson.

D, Setyono \& S, Sutarni. (2013). Kesalahan Menyelesaikan Masalah Matematika dalam Bentuk Soal Cerita Pokok Bahasan Aritmetika Sosial. Seminar Nasional Pendidikan Matematika, Surakarta.

Kane, R. B., Byrne, M. A., \& Hater, M. A. (1974). Helping children read mathematics. New York: American Book.

L.S. Shulman. (1970). Psychology and Mathematics Education. Chicago: University of Chicago Press Chicago. 
NCTM. (2000). Principles and Standarts for School Mathematics. Reston: VA.

Pippig, G. (1977). Psychologische tIberlegungen zur Uiberwindung von denkfehlern. Mathematik in der Schule, 15, 26-41.

Radatz, H. (2013). Error Analysis in Mathematic Education. National Council of Teachers of Mathematics. Journal for Research in Mathematics Education, 10 (3), 163-172.

Sajadi M, Amiripour P, \& Malkhalifeh M.R. (2013). The Examining Mathematical Word Problems Solving Ability under Efficient Representation Aspec. Mathematics Education Trends and Research, 1-11.

Tello, E.A. (2010). Making Mathematics Word Problems Reliable Measures of Student Mathematics Abilities. Journal of The Mathematics Education, 3 (1), 15-26. 